\title{
Characterisation of dermonecrotic toxin-producing strains of Pasteurella multocida subsp. multocida isolated from man and swine
}

\author{
P.-Y. DONNIO, A. ALLARDET-SERVENT*, M. PERRIN, F. ESCANDE† and J.-L. AVRIL \\ Laboratoire de Bactériologie-Virologie, UPRES 12-34 Microbiologie Université de Rennes, rue Léon Bernard, \\ 35043 Rennes, *INSERM U341, Faculté de Médecine, 30000 Nimes and †Laboratoire des Pasteurella, Institut \\ Pasteur, 75724 Paris, France
}

\begin{abstract}
Thirty-six isolates, from man or swine, of Pasteurella multocida subsp. multocida producing $(n=13)$ or not producing $(n=23)$ the dermonecrotic toxin $(\mathrm{DNT})$ were studied by numerical analysis, capsular typing and ribotyping. Toxigenic strains were also characterised by restriction fragment length polymorphism (RFLP) of the toxA gene and pulsed-field gel electrophoresis (PFGE). Numerical analysis differentiated the Pasteurella species and subspecies, but did not discriminate between toxigenic and nontoxigenic strains. RFLP demonstrated that toxA was located in a conserved part of the chromosome of all toxigenic strains. Ribotyping provided evidence of a close association between DNT production and one of the six EcoRI ribotypes designated as E2. In contrast, PFGE provided evidence for significant DNA polymorphism amongst the toxigenic strains. Results of phenotypic and genotypic studies suggested that toxigenic strains do not form a clone within the subspecies multocida. No difference was found between toxigenic strains of porcine or human origin by biochemical characterisation, capsular serotyping or genomic typing methods.
\end{abstract}

\section{Introduction}

The genus Pasteurella includes gram-negative bacteria that are commensal organisms of mucosal surfaces in a wide variety of birds and mammals. The most common species, $P$. multocida, is widespread in wild and domestic animals. DNA-DNA hybridisation studies led to the division of the multocida species into three subspecies designated multocida, septica and gallicida [1]. Most strains isolated from swine are P. multocida subsp. multocida [2] and some of them produce a dermonecrotic toxin (DNT) involved in the pathogenesis of atrophic rhinitis, an economically significant disease. Atrophic rhinitis is characterised by a haemorrhagic discharge, sneezing, torsion of the snout caused by the loss of turbinate bone and weight loss [3,4]. DNT-producing strains are isolated mainly from swine, but also from dogs, cats and rabbits [5].

In two previous studies, it was suggested that colonisation or infection of the respiratory tract in man by toxigenic or non-toxigenic $P$ multocida subsp.

Received 17 Nov. 1997; revised version received 7 May 1998; accepted 12 May 1998.

Corresponding author: Dr P-Y. Donnio. multocida strains could result from exposure to swine $[6,7]$. In animals, DNT induces lesions in liver and kidney $[3,8,9]$ and carriage of toxin-producing strains could be harmful to farmers, especially those suffering from chronic pulmonary disease. Human carriage could be of concern also in the control of atrophic rhinitis in swine. Characterisation of Pasteurella isolates from man has been done previously $[10,11]$, but these were not isolates cultured from people after exposure to swine. Recently, P. multocida genomic typing methods have been used successfully for epidemiological purposes; for example, to compare strains from wild and domestic animals [12], to study transmission of strains in swine herds [13] and to compare strains isolated from farmers [14]. The objective of the present work was to perform phenotypic and genotypic studies of toxigenic isolates and to investigate the possible transmission of DNT-producing strains from swine to people living in rural areas.

\section{Materials and methods}

\section{Bacterial strains}

The bacterial strains examined, including reference strains and clinical isolates, are listed in Table 1. A 
Table 1. Characteristics of the Pasteurella isolates investigated

\begin{tabular}{|c|c|c|c|c|c|c|c|c|}
\hline $\begin{array}{l}\text { Taxon (number of } \\
\text { strains) }\end{array}$ & $\begin{array}{l}\text { Source* and isolate } \\
\text { designation }\end{array}$ & Host & Specimen & $\begin{array}{l}\text { Capsular } \\
\text { type }\end{array}$ & $\begin{array}{l}\text { DNT } \\
\text { production }\end{array}$ & $\begin{array}{l}\text { EcoRI } \\
\text { ribotype }\end{array}$ & $\begin{array}{l}\text { HindIII } \\
\text { ribotype }\end{array}$ & $\begin{array}{l}\text { PFGE } \\
\text { pattern }\end{array}$ \\
\hline P. multocida & NCTC $10322^{\mathrm{T}}$ & Pig & & A & - & E1 & $\mathrm{H} 9$ & \\
\hline \multirow[t]{35}{*}{ subsp. multocida (36) } & NCTC 12177 & Pig & & A & + & $\mathrm{E} 2$ & $\mathrm{H} 7$ & I \\
\hline & NCTC 12178 & Pig & & $\mathrm{D}$ & + & E2 & H8 & II \\
\hline & CIP 5684 & Human & CSF & $\mathrm{D}$ & - & E1 & $\mathrm{H} 1$ & \\
\hline & CIP 5724 & Human & Wound & $\mathrm{D}$ & - & E5 & H1 & \\
\hline & CIP 5730 & Human & Sinus washing & $\mathrm{D}$ & + & E1 & $\mathrm{H} 8$ & III \\
\hline & PMR 1 & Human & Pleural effusion & $\mathrm{D}$ & - & E1 & H6 & \\
\hline & PMR 9 & Human & Sputum & A & - & $\mathrm{E} 2$ & $\mathrm{H} 10$ & \\
\hline & PMR 15 & Human & Dog bite & $\mathrm{D}$ & - & E3 & H11 & \\
\hline & PMR 17 & Human & Dog bite & $\mathrm{D}$ & - & E4 & H8 & \\
\hline & PMR 19 & Human & Dog bite & A & - & E4 & $\mathrm{H} 9$ & \\
\hline & PMR 23 & Human & Sputum & A & + & E1 & $\mathrm{H} 7$ & III \\
\hline & PMR 29 & Human & Animal bite & A & - & E6 & H11 & \\
\hline & PMR 35 & Human & Pleural effusion & A & - & E1 & $\mathrm{H} 8$ & \\
\hline & PMR 40 & Human & Bronchial aspiration & $\mathrm{D}$ & - & E1 & H8 & \\
\hline & PMR 41 & Human & Sputum & A & - & E1 & $\mathrm{H} 10$ & \\
\hline & PMR 42 & Human & Sputum & A & - & E1 & H5 & \\
\hline & PMR 43 & Human & Sputum & A & + & $\mathrm{E} 2$ & H11 & IV \\
\hline & PMR 46 & Human & Sputum & A & + & E2 & $\mathrm{H} 10$ & $\mathrm{~V}$ \\
\hline & PMR 51 & Human & Sputum & $\mathrm{D}$ & - & E1 & H5 & \\
\hline & PMR 78 & Human & Cat bite & $\mathrm{D}$ & - & E1 & $\mathrm{H} 2$ & \\
\hline & PMR 79 & Human & Bronchial aspiration & A & + & $\mathrm{E} 2$ & H11 & VI \\
\hline & PMR 85 & Human & Pleural effusion & A & + & E1 & $\mathrm{H} 8$ & VII \\
\hline & PMR 86 & Human & Wound & $\mathrm{D}$ & - & E1 & $\mathrm{H} 12$ & \\
\hline & PMR 87 & Human & Cat bite & A & - & E1 & H6 & \\
\hline & PMR 118 & Human & Oropharynx & $\mathrm{D}$ & - & $\mathrm{E} 1$ & $\mathrm{H} 8$ & \\
\hline & PMR 125 & Human & Oropharynx & A & - & E1 & $\mathrm{H} 4$ & \\
\hline & PMR 126 & Human & Oropharynx & A & - & E1 & H8 & \\
\hline & PMR 127 & Human & Oropharynx & A & - & $\mathrm{E} 1$ & H11 & \\
\hline & PMR 130 & Human & Oropharynx & $\mathrm{D}$ & + & $\mathrm{E} 2$ & H11 & VIII \\
\hline & SPP 3351 & Pig & & $\mathrm{D}$ & - & E1 & $\mathrm{H} 3$ & \\
\hline & SPP 6705 & Pig & & $\mathrm{D}$ & - & E1 & H5 & \\
\hline & SPP 7294 & Pig & & $\mathrm{D}$ & + & $\mathrm{E} 2$ & H1 1 & IX \\
\hline & SPP 10814 & Pig & & $\mathrm{D}$ & + & $\mathrm{E} 2$ & $\mathrm{H} 2$ & $\mathrm{X}$ \\
\hline & IEMVT D2 & Pig & & $\mathrm{D}$ & + & $\mathrm{E} 2$ & $\mathrm{H} 8$ & III \\
\hline & IEMVT D706 & Pig & & $\mathrm{D}$ & + & $\mathrm{E} 2$ & H8 & $\mathrm{XI}$ \\
\hline $\begin{array}{l}\text { P. multocida } \\
\text { subsp. septica }(1)\end{array}$ & CIP A $125^{\mathrm{T}}$ & Human & & ND & - & ND & ND & \\
\hline $\begin{array}{l}\text { P. multocida } \\
\text { subsp. gallicida (1) }\end{array}$ & NCTC $10204^{T}$ & Bovine & & ND & - & ND & ND & \\
\hline$P$ canis $(1)$ & NCTC $11621^{\mathrm{T}}$ & Dog & & ND & - & ND & ND & \\
\hline P. dagmatis (1) & NCTC $11617^{\mathrm{T}}$ & Human & & ND & - & ND & ND & \\
\hline P. stomatis (1). & SSI P365 & Human & & ND & - & ND & ND & \\
\hline
\end{tabular}

$\mathrm{ND}$, not determined.

*NCTC, National Collection of Type Cultures, London; CCIP, Collection de 1'Institut Pasteur, Paris, France: PMR, Collection de Pasteurella, Laboratoire de Microbiologie, Faculté de Médecine, Rennes, France; SPP, Station de Pathologie Porcine, Ploufragan, France; IEMVT, CIRADEMVT, Maisons-Alfort, France; SSI, Statens Seruminstitut, Copenhagen, Denmark; ${ }^{\mathrm{T}}$ designates type strain.

stock culture of each isolate was made in Tryptose Broth (Difco) with glycerol $20 \% \mathrm{v} / \mathrm{v}$ and frozen at $-80^{\circ} \mathrm{C}$. For each experiment, stock cultures were streaked on Trypticase-soy Agar supplemented with horse blood (bioMérieux) $5 \% \mathrm{v} / \mathrm{v}$. Cultures were incubated at $37^{\circ} \mathrm{C}$ for $18 \mathrm{~h}$.

\section{Enzyme-linked immunosorbent assay}

Differentiation of toxigenic from non-toxigenic isolates was by an enzyme-linked immunosorbent assay (ELISA; Dakopatts) with two monoclonal antibodies, as described previously [15]. Results of the tests were expressed according to Foged et al. [16], as the relative absorbance, i.e., the ratio between the absorbance of the test strain and the absorbance of the toxigenic reference strain NCTC 12178, both measured at a wavelength of $492 \mathrm{~nm}$. A relative absorbance of 0.40 was taken as a positive result.

\section{Biochemical characterisation and numerical analysis}

All strains were characterised by 78 biochemical tests with three identification kits - API 20E, API ZYM and API $50 \mathrm{CH}$ (bioMérieux). API ZYM strips were inoculated with bacterial suspension in distilled water at a concentration equivalent to 4 MacFarland units. API 20E and API 50CH strips were inoculated with bacterial suspension, at 3 MacFarland units, in M63 solution ( $\mathrm{pH} 7.0$ ) supplemented with Bacto Tryptone (Difco) $0.5 \% \mathrm{w} / \mathrm{v}$ and yeast extract $0.02 \% \mathrm{w} / \mathrm{v}$ as described previously (F. Escande, PhD thesis, 1985, Université Paris Sud). API ZYM, API 20E and API $50 \mathrm{CH}$ strips were incubated for 4,48 and $96 \mathrm{~h}$, respectively, at $37^{\circ} \mathrm{C}$, and read according to the manufacturer's instructions. Data were recorded in binary code and a numerical analysis was performed with the Taxan program (University of Maryland). 
Cluster analysis of the results was performed by the weighted-average-linkage method along with the coefficient of Jacard $\left(\mathrm{S}_{\mathrm{J}}\right)$.

\section{Serotyping}

Capsular type was determined by a passive haemagglutination test with a hyperimmune rabbit serum according to the method of Carter [17].

\section{Synthesis of digoxigenin-labelled probes}

The complete sequence of tox $\mathrm{A}$, the gene coding for the DNT, was obtained from the EMBL bank (access no. X52478) and analysed with the PCRare ${ }^{\circledR}$ program (Eurogenetec) [18] to design two primers Pml and Pm2 (Table 2) which were used to amplify a 185-bp product corresponding to the $5^{\prime}$ end of a toxA-specific probe described by Kamps et al. [19]. Polymerase chain reactions (PCR) and nested PCR were performed according to Griffais et al. [20]. Five toxigenic strains and five non-toxigenic strains were tested to assess amplification specificity. Incorporation of digoxigeninlabelled dUTP was then performed by nested PCR with an amplified product from the reference strain CIP 5730 and two 20-mer primers, $\mathrm{Pm} 3$ and $\mathrm{Pm} 4$, corresponding to the $3^{\prime}$ flanking sequences of Pm1 and $\mathrm{Pm} 2$, respectively (Table 2 ).

A 1455-bp digoxigenin-labelled probe recognising the 16S rRNA gene was synthesised by a similar nested procedure, with the primers P0mod and PC5 described by Wilson et al. [21] (Table 2), $0.1 \mu \mathrm{g}$ of Escherichia coli ATCC 25922 DNA as template, and primers I0 and IC5 (Table 2) internal to the two previous primers.

\section{Slot-blot assay for toxA detection}

DNA was extracted as described by Boom et al. [22], denatured by heating at $95^{\circ} \mathrm{C}$, loaded into wells of a slot-blot apparatus (Hoefer Scientific Instruments) and blotted on to a Hybond-N membrane (Amersham). To assess the sensitivity of the probe, 10-fold dilutions of DNA from strain CIP 5730, from $1 \mu \mathrm{g}$ to $100 \mathrm{pg}$, were slot-blotted and hybridised according to the manufacturer's recommendations (Boehringer Mannheim).

\section{Ribotyping and toxA restriction polymorphism}

DNA was extracted by a phenol-chloroform procedure, precipitated by ethanol, dried and resuspended in $10 \mathrm{mM}$ Tris, $0.1 \mathrm{mM}$ EDTA, pH 7.5. DNA solution was digested with EcoRI, HindIII and PvuII (Boehringer Mannheim) for analysis of toxA polymorphism (toxigenic strains), or by EcoRI and HindIII for ribotyping. Restrictions endonuclease digestions were performed for $3 \mathrm{~h}$ at $37^{\circ} \mathrm{C}$ and then DNA fragments were separated by gel electrophoresis in agarose $0.8 \% \mathrm{w} / \mathrm{v}$, transferred to a Hybond-N nylon membrane (Amersham) and hybridised with DNA probes for $16 \mathrm{~S}$ rRNA or toxA genes.

\section{Pulsed-field gel electrophoresis of total DNA}

Restriction endonuclease analysis by pulsed-field gel electrophoresis (PFGE) was performed after digestion of genomic DNA with the infrequently cleaving restriction endonuclease ApaI. High mol.-wt DNA embedded in agarose was prepared by the procedure of Allardet-Servent et al. [23]. Digests were separated by PFGE in agarose (Appligene) $1 \% \mathrm{w} / \mathrm{v}$ with a Gene Navigator System apparatus (Pharmacia Biotech). A gradient of pulse time of $8-40 \mathrm{~s}$ was applied for $40 \mathrm{~h}$ at $150 \mathrm{~V}$.

\section{Results}

\section{Identification of toxigenic strains}

Six P. multocida subsp. multocida porcine isolates were toxigenic by ELISA: the two reference strains NCTC 12177 and NCTC 12178 and four clinical isolates IEMVT D2, IEMVT D706, SPP 7294 and SPP 10814. As reported previously [7], seven isolates from man were toxigenic: the reference strain CIP 5730 and six clinical isolates, PMR 23, PMR 43, PMR 46, PMR 79, PMR 85 and PMR 130 (Table 1). Twenty-three $P$. multocida subsp. multocida isolates and all strains belonging to other taxa, did not produce DNT; in the ELISA test all gave a relative absorbance of $<0.10$. Capsular types of toxigenic isolates from swine and man were D (five and two isolates, respectively), or A (one and five isolates, respectively) (Table 1).

After PCR with primers Pm1 and Pm2 specific for the

Table 2. Primers used in the synthesis of digoxigenin-labelled probes by PCR

\begin{tabular}{lll}
\hline Target gene & Primer & Nucleotide sequence \\
\hline $16 \mathrm{~S}$ rRNA & P0mod $^{*}$ & AGAGTTTGATCATGG \\
& PC5* & TACCTTGTTACGACTT \\
& I0 & CTCAGATTGAACGCT \\
& IC5 & GTGGGGTCAGTACTT \\
toxA $($ P. multocida $)$ & $\mathrm{Pm} 1$ & TTTTTCACTGAAGAACAAGCTTTAG \\
& $\mathrm{Pm} 2$ & TTTATTTCCTCCTAATCTTCGTAAC \\
& $\mathrm{Pm} 3$ & CTCAACGCTTTGAAATAGTA \\
& $\mathrm{Pm} 4$ & ACAACTAAAGGTTGATTTC \\
\hline
\end{tabular}

*From reference [21]. 
toxA gene and electrophoresis, a single band at the expected size of $185 \mathrm{bp}$ was visualised only with the five toxigenic isolates tested. In the slot-blot assay with the toxA probe, a marked signal was detected with $10 \mathrm{ng}$ of DNA from $P$. multocida strain CIP 5730 , and the probe correctly identified the same 13 toxigenic isolates identified by ELISA. No falsepositive result nor background signal was observed with the 23 non-toxigenic isolates.

\section{Numerical analysis}

Results of the numerical analysis with 78 biochemical tests are shown in Fig. 1. At a similarity level of $75 \%$, all the $P$. multocida subsp. multocida isolates were members of a single cluster. At the similarity level of $80 \%$, there were four distinct areas, A, B, C and D, in the dendrogram. These four areas contained only the 36 isolates of $P$. multocida subsp. multocida, distributed as follows: A, 25 isloates; B, 3 isolates; C, 2 isolates; D, 6 isolates. The dendrogram did not clearly reflect the origin of the isolates, but most porcine isolates (except the type strain NCTC 10322) were linked to each other at a similarity level of $\geqslant 91 \%$, and were located in area A. The human isolates were randomly scattered about the four areas. All but one toxigenic isolate were located in the larger area A, and did not form a subphenon of the phenon assigned as $P$. multocida subsp. multocida.

\section{Restriction polymorphism}

After digestion of DNA by HindIII, EcoRI or PvuII, the toxA probe hybridised with unique restriction fragments of $1.5,5.2$ and $26.0 \mathrm{~kb}$, respectively, in all the toxigenic isolates.

With DNA digested by EcoRI, the $16 \mathrm{~S}$ rRNA probe hybridised with 8-10 restriction fragments (Fig. 2). Six different ribotypes (E1-6) were observed in the 36 isolates, with E1 (20 isolates) and E2 (11 isolates) being the most common (Fig. 2 and Table 1). These two ribotypes differed by a single band of $7.2 \mathrm{~kb}$ which was present in E2, but not in E1 (Fig. 2). Ribotype E1 consisted of 3 toxigenic and 17 nontoxigenic isolates. Ribotype E2 consisted of 10 toxigenic and 1 non-toxigenic isolates. Ribotypes E3, E4, E5 and E6 each consisted of one or two nontoxigenic isolates. After HindIII restriction, four to eight fragments were visualised and 12 restriction paterns were obtained with the 36 isolates (Fig. 2). There was no difference in the distribution of ribotypes as far as toxin production was concerned: $\mathrm{H} 8$, the most common pattern, included five toxigenic and five non-toxigenic isolates.

After ApaI digestion and separation of DNA fragments by PFGE, 11 restriction patterns (designated with a roman number $\mathrm{I}-\mathrm{XI}$ ) were found among the 13 toxigenic isolates. The epidemiologically unrelated strains CIP5730, PMR 23 and IEMVT D2 had the same pattern III (Table 1).

\section{Discussion}

Cases of pasteurellosis in man are usually categorised as related or unrelated to animal bites or scratches, and most infections unrelated to animal bites are respiratory tract infections. Pasteurella spp. are not common inhabitants of the upper respiratory tract of man, but healthy carriage is frequent in pig farmers [6] and toxigenic strains can be isolated from the respiratory tracts of people living or working near swine herds. In contrast, toxigenic strains are rarely if ever isolated from bite infections $[7,24]$ or bacteraemias (F. Escande, unpublished observations). Toxigenic isolates from swine have been characterised by outer-membrane proteins or lipopolysaccharide electrophoretic patterns $[25,26]$, and several studies have investigated the specificity of $P$. multocida for different species of animals $[2,11]$. However, toxigenic strains from man and swine have not been compared.

In numerical analysis, a similarity level of $75 \%$ has valid taxonomic significance for the $\mathrm{S}_{\mathrm{J}}$ coefficient and has been suggested as a good criterion for phenetic species [27]. Cutting the dendrogram at the $75 \%$ level allowed separation of the different taxa belonging to the genus Pasteurella, including the three subspecies of $P$. multocida. Numerical analysis of Pasteurella isolates from human infections has been reported previously by Talbot and Sneath [11], with delineation of a homogenous group of $P$. multocida isolates which included isolates from cat bites and 'internal' isolates (i.e., from infections not involving direct inoculation). In the present analysis, most porcine isolates belonged to the same group. In contrast, human isolates were heterogeneous; eight of them were related to the porcine group in the dendrogram at a similarity level of $\geqslant 91 \%$ (Fig. 1). This possibly reflects the fact that man is susceptible to acquisition of infection from several animal species. Moreover, the dendrogram clearly demonstrated that the toxigenic isolates did not form a subphenon of the phenon $P$. multocida subsp. multocida and, consequently, biochemical tests could not be used for their identification.

Like biochemical tests, capsular serotyping failed to identify toxigenic isolates: porcine and human isolates were D or A type, which are common types in all animal species. Toxigenic strains of capsular types A or D both occur in swine, but type D strains are more frequently associated with atrophic rhinitis [3]. Type A capsule contains large amounts of hyaluronic acid which confers a 'watery' mucoid phenotype to colonies, as noted previously for isolates from the respiratory tract $[28,29]$, and confers a greater ability to colonise mucosal surfaces and to resist phagocytosis by polymorphonuclear leucocytes [30].

DNA probes for toxA [19] and, more recently, PCR [31] have been described as useful tools for diagnostic purposes. The 135-bp DNA probe specific for toxA 


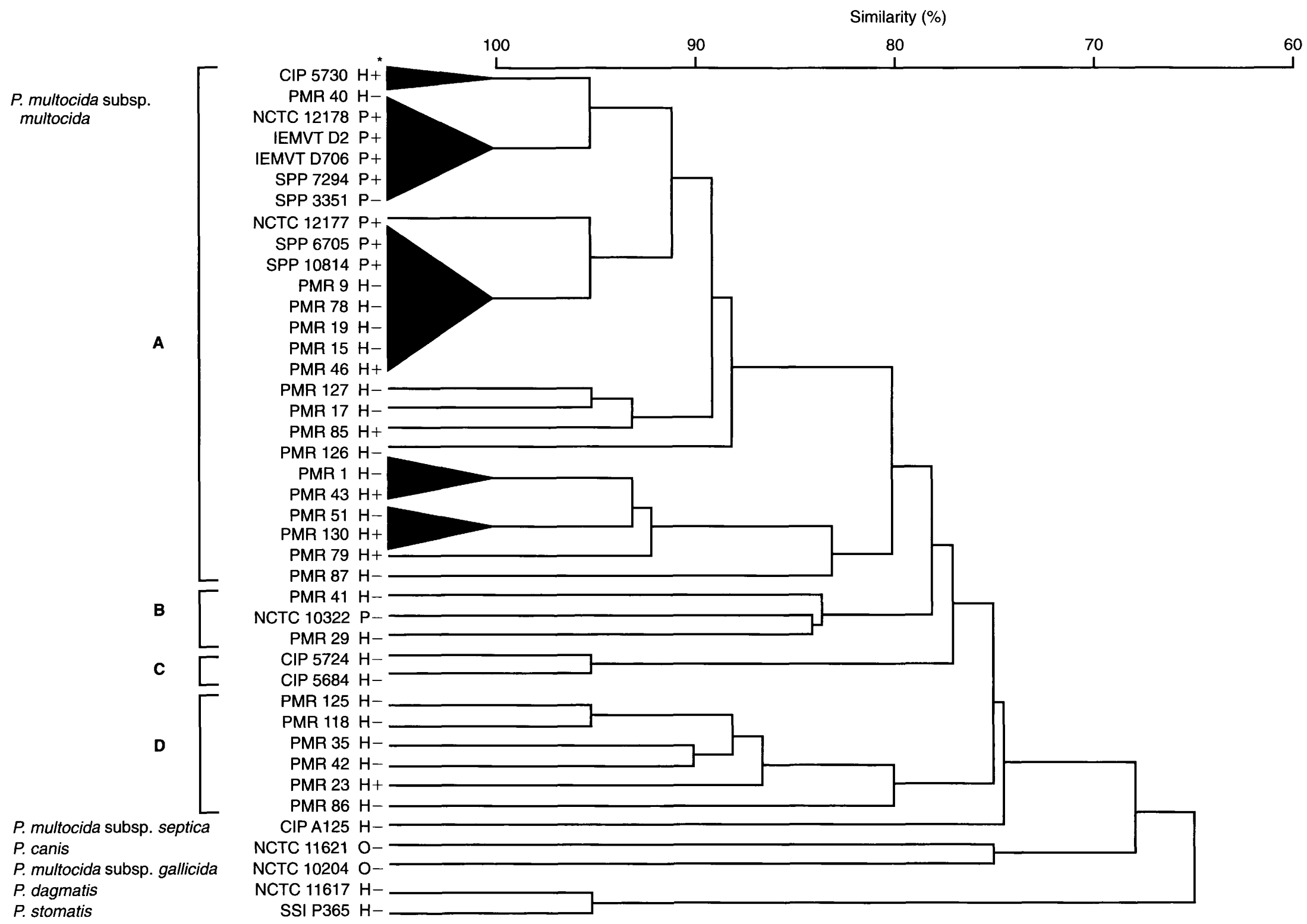

Fig. 1. Dendrogram showing relationships among Pasteurella spp. isolates based on the $\mathrm{S}_{\mathrm{J}}$ coefficient and the weighted-average-linkage analysis. 


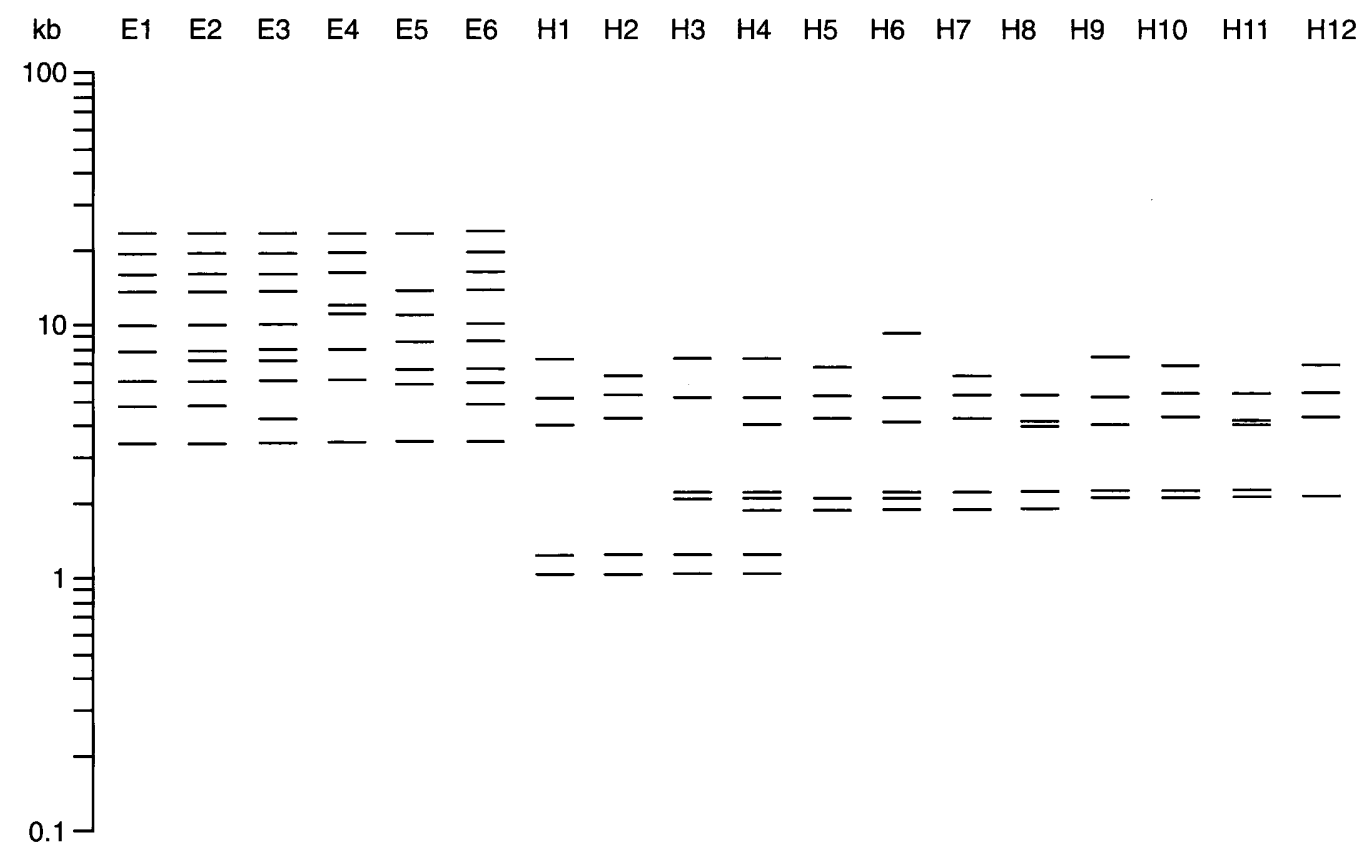

$\begin{array}{llllllllllllllllllll}\text { Number of strains } & 20 & 11 & 1 & 2 & 1 & 1 & 2 & 2 & 1 & 1 & 3 & 2 & 2 & 10 & 2 & 3 & 7 & 1 \\ \text { Number of toxigenic strains } & 3 & 10 & 0 & 0 & 0 & 0 & 0 & 1 & 0 & 0 & 0 & 0 & 2 & 5 & 0 & 1 & 4 & 0\end{array}$

Fig. 2. Schematic representation and distribution of EcoRI (E1-6) and HindIII (H1-12) ribotypes among 36 isolates of P. multocida subsp. multocida.

was tested here in a slot-blot hybridisation assay and compared with a commercially available ELISA. The results were in complete agreement and the slot-blot assays gave a positive reaction with $10 \mathrm{ng}$ of DNA of a toxigenic reference strain. As reported in previous studies, only the DNT-producing isolates possessed the toxA gene [19].

Results of digestion by HindIII were in agreement with a previous report [19]: two sites were present in the toxA gene and, after restriction, the 135-bp toxA probe hybridised with a $1.5-\mathrm{kb}$ fragment in all toxigenic strains. Polymorphism of the flanking sequences next to the gene was explored by EcoRI (one restriction site in $t o x \mathrm{~A}$ ) and $P v u$ II (no restriction site in toxA). No polymorphism was found with the toxA probe: after digestion by either EcoRI or $P v u \mathrm{II}$, a single pattern was observed with all toxigenic isolates. It has been reported that after Sau IIIa restriction and hybridisation with a tox A probe, toxigenic $P$. multocida subsp. multocida strains exhibited the same banding pattern [32] and that toxA was located on a conserved part of the genome [33]. Flanking sequences of tox A have homology with 22 bacteriophages isolated from $P$. multocida, and induction of toxigenic strains by mitomycin $\mathrm{C}$ leads to liberation of DNA fragments which hybridise with a tox A probe [33]. Consequently, some authors have proposed an exogenous origin of toxA [34]. The ribotype E2 differs from the most common ribotype E1 by only one 7.2-kb fragment, and is closely associated to toxin production. We suggest that the ribotype E2 could be the result of a phage conversion of ribotype E1 strains, by insertion of exogenous, highly conserved DNA into the chromosome. In contrast with EcoRI ribotyping, PFGE results provided evidence for significant DNA polymorphism of the toxigenic isolates: 10 ApaI macrorestriction patterns were found with the 13 isolates. Analysis of PFGE patterns of $P$. multocida serotype B has been useful to distinguish avirulent strains and virulent strains that cause haemorrhagic septicaemia in cattle, with homogeneity among the Asian haemorrhagic septicaemia strains [35]. The results of the present study do not support the hypothesis that DNT-producing strains form a clone within the subspecies $P$. multocida subsp. multocida. Moreover, phenetic characters and genomic typing methods do not discriminate between toxigenic isolates of porcine or human origin and may suggest colonisation of people from a porcine reservoir.

We thank C. Legoff from CIRAD-EMVT for providing the rabbit sera for serotyping. This work was supported by grants from the Direction de al Recherche et des Etudes Doctorales du Ministère de l'Education Nationale (DRED 92/66), and from the Fondation pour la Recherche Médicale.

\section{References}

1. Mutters R, Ihm P, Pohl S, Frederiksen W, Mannheim W. Reclassification of the genus Pasteurella Trevisan 1887 on the basis of deoxyribonucleic acid homology, with proposals for the new species Pasteurella dagmatis, Pasteurella canis, 
Pasteurella stomatis, Pasteurella anatis, and Pasteurella langaa. Int $J$ Syst Bacteriol 1985; 35: 309-322.

2. Heddleston KL. Physiologic characteristics of 1,268 cultures of Pasteurella multocida. Am J Vet Res 1976; 37: 745-747.

3. Chanter N, Rutter JM. Pasteurellosis in pigs and the determinant of virulence of toxigenic Pasteurella multocida. In: Adlam C, Rutter JM (eds) Pasteurella and pasteurellosis. London, Academic Press. 1989: 161-195.

4. Chanter N. Molecular aspects of the virulence of Pasteurella multocida. Can J Vet Res 1990; 54 Suppl: S45-S47.

5. Nielsen JP, Bisgaard M, Pedersen KB. Production of toxin in strains previously classified as Pasteurella multocida. APMIS 1986; 94: 203-204.

6. Avril J-L, Donnio P-Y, Pouedras P. Selective medium for Pasteurella multocida and its use to detect oropharyngeal carriage in pig breeders. $J$ Clin Microbiol 1990; 28: 1438-1440.

7. Donnio PY, Avril JL, André PM, Vaucel J. Dermonecrotic toxin production by strains of Pasteurella multocida isolated from man. J Med Microbiol 1991; 34: 333-337.

8. Cheville NF, Rimler RB, Thurston JR. A toxin from Pasteurella multocida type $\mathrm{D}$ causes acute hepatic necrosis in pigs. Vet Pathol 1988; 25: 518-520.

9. Cheville NF, Rimler BR. A protein toxin from Pasteurella multocida type $\mathrm{D}$ causes acute and chronic hepatic toxicity in rats. Vet Pathol 1989; 26: $148-157$.

10. Oberhofer TR. Characteristics and biotypes of Pasteurella multocida isolated from humans. J Clin Microbiol 1981; 13: 566-571.

11. Talbot JM, Sneath PHA. A taxonomic study of Pasteurella septica especially of strains isolated from human sources. $J$ Gen Microbiol 1960; 22: 303-311.

12. Snipes KP, Hirsh DC, Kasten RW et al. Use of an rRNA probe and restriction endonuclease analysis to fingerprint Pasteurella multocida isolated from turkeys and wildlife. J Clin Microbiol 1989; 27: 1847-1853.

13. Zhao G, Pijoan C, Murtaugh MP, Molitor TW. Use of restriction endonuclease analysis and ribotyping to study of Pasteurella multocida in closed swine herds. Infect Immun 1992; 60: 1401-1405.

14. Donnio PY, Le Goff C, Avril JL, Pouedras P, Gras-Rouzet S. Pasteurella multocida: oropharyngeal carriage and antibody response in breeders. Vet Res 1994; 25: 8-15.

15. Foged NT. Quantitation and purification of the Pasteurella multocida toxin by using monoclonal antibodies. Infect Immun 1988; 56: 1901-1906.

16. Foged NT, Nielsen JP, Pedersen KB. Differentiation of toxigenic from nontoxigenic isolates of Pasteurella multocida by enzyme-linked immunosorbent assay. $J$ Clin Microbiol 1988; 26: $1419-1420$.

17. Carter GR. Studies on Pasteurella multocida. II. A haemagglutination test for the identification of serological types. Am J Vet Res 1955; 16: $481-484$

18. Griffais R, Andre PM, Thibon M. K-tuple frequency in the human genome and polymerase chain reaction. Nucleic Acids Res 1991; 19: 3887-3891.

19. Kamps AMIE, Buys WECM, Kamp EM, Smits MA Specificity of DNA probes for the detection of toxigenic
Pasteurella multocida subsp. multocida strains. J Clin Microbiol 1990; 28: 1858-1861.

20. Griffais R, André PM, Thibon M. Synthesis of digoxigeninlabelled DNA probe by polymerase chain reaction: application to Epstein-Barr virus and Chlamydia trachomatis. Res Virol 1990; $141331-335$.

21. Wilson $\mathrm{KH}$, Blitchington RB, Greene RC. Amplification of bacterial 16S ribosomal DNA with polymerase chain reaction. $J$ Clin Microbiol 1990; 28: 1942-1946.

22. Boom R, Sol CJA, Salimans MMM, Jansen CL, Wertheim-van Dillen PME, van der Noorda J. Rapid and simple method for purification of nucleic acids. $J$ Clin Microbiol 1990; 28: 495-503.

23. Allardet-Servent A, Bouziges N, Carles-Nurit MJ, Bourg G, Gouby A, Ramuz M. Use of low-frequency-cleavage restriction endonucleases for DNA analysis in epidemiological investigations of nosocomial bacterial infections. J Clin Microbiol 1989; 27: 2057-2061.

24. Holst E, Rollof J, Larsson L, Nielsen JP. Characterization and distribution of Pasteurella species recovered from infected humans. J Clin Microbiol 1992; 30: 2984-2987.

25. Lugtenberg $B$, van Boxtel $R$, de Jong $M$. Atrophic rhinitis in swine: correlation of Pasteurella multocida pathogenicity with membrane protein and lipopolysaccharide patterns. Infect Immun 1984; 46: 48-54.

26. Vasfi Marandi M, Harel J, Mittal KR. Identification by monoclonal antibodies of serotype D strains of Pasteurella multocida representing various geographic origins and host species. J Med Microbiol 1997; 46: 603-610.

27. Sneath PHA, Sokal RR (eds). Numerical taxonomy: the principles and practice of numerical classification. San Francisco, WH Freeman. 1973

28. Heddleston KL, Wessmann G. Characteristics of Pasteurella multocida of human origin. J Clin Microbiol 1975; 1: 377-383.

29. Henriksen SD, Jyssum K. A study of some Pasteurella strains from the human respiratory tract. Acta Pathol Microbiol Scand 1961; 51: 354-368.

30. Maheswaran SK, Thies ES. Influence of encapsulation on phagocytosis of Pasteurella multocida by bovine neutrophils. Infect Immun 1979; 26: 76-81.

31. Lichtensteiger CA, Steenbergen SM, Lee RM, Polson DD, Vimr ER. Direct PCR analysis for toxigenic Pasteurella multocida. J Clin Microbiol 1996; 34: 3035-3039.

32. Frandsen PL, Foged NT, Petersen SK. Characterization of toxin from different Pasteurella multocida strains. Proceedings of the 11th International Pig Congress, Lausanne, 1990; 59.

33. Andresen LO, Petersen SK, Christiansen C, Nielsen JP. Studies on the location of the Pasteurella multocida toxin gene toxA. Proceedings of the 11 th International Pig Congress, Lausanne, $1990 ; 60$

34. Lax AJ, Chanter N, Pullinger GD, Higgins T, Staddon JM, Rozengurt E. Sequence analysis of the potent mitogenic toxin of Pasteurella multocida. FEBS Lett 1990; 277: 59-64.

35. Townsend KM, Dawkins HJ, Papadimitriou JM. Analysis of haemorrhagic septicemia-causing isolates of Pasteurella multocida by ribotyping and field alternation gel electrophoresis (FAGE). Vet Microbiol 1997; 57: 383-395. 